\title{
Facile and Rapid Synthesis of Microwave Assisted Pd Nanoparticles as Non-Enzymatic Hydrogen Peroxide Sensor
}

\author{
Ozlem Sahin ${ }^{1, *}$, Hilal Kivrak ${ }^{2}$, Arif Kivrak ${ }^{3}$, Hilal Çelik Kazıcl ${ }^{2}$, Orhan Alal $^{2}$, Dilan Atbas ${ }^{2}$ \\ ${ }^{1}$ Chemical Engineering Department, Selcuk University, 42031, Konya Turkey \\ ${ }^{2}$ Chemical Engineering Department, Yüzüncü Yıl University, 65081, Van Turkey \\ ${ }^{3}$ Department of Chemistry, Yüzüncü Y1l University, 65081, Van Turkey \\ *E-mail: hilalkivrak@gmail.com, hilalkivrak@yyu.edu.tr
}

doi: $10.20964 / 2017.01 .26$

Received: 18 May 2016 / Accepted: 29 October 2016 / Published: 12 December 2016

\begin{abstract}
Carbon supported Pd catalyst was prepared with microwave-assisted polyol method (M-Pd@C) and investigated sensing activity for non-enzymatic hydrogen peroxide $\left(\mathrm{H}_{2} \mathrm{O}_{2}\right)$. Moreover, M-Pd@C and $\mathrm{Pd} @ \mathrm{C}$ catalyst which synthesized via polyol method (P-Pd@C) were compared to each other in terms of electrocatalytic activity. X-ray diffraction (XRD), X-ray photo electron spectroscopy (XPS), scanning electron microscopy (SEM) and transmission electron microscopy (TEM) were used to investigate structural and morphological properties of these catalysts. Furthermore, electrochemical measurements were performed via cyclic voltammetry $(\mathrm{CV})$, chronoamperometry (CA) techniques. $\mathrm{CV}$ results exhibited that $\mathrm{M}-\mathrm{Pd} / \mathrm{C}$ catalyst showed perfect electrocatalytic activity in terms of reduction of $\mathrm{H}_{2} \mathrm{O}_{2} . \mathrm{M}-\mathrm{Pd} / \mathrm{C}$ catalyst showed a fast response of less than $7 \mathrm{~s}$ with a linear range of $5.0 \times 10^{-3}-11.0$ $\mathrm{mM}$ and a relatively low detection limit of $1.2 \mu \mathrm{M}$ amperometric response. $\mathrm{M}-\mathrm{Pd} / \mathrm{C}$ catalyst exhibited great selectivity for detecting $\mathrm{H}_{2} \mathrm{O}_{2}$ in the existence of several hindering species such as uric acid and ascorbic acid.
\end{abstract}

Keywords: Pd nanoparticles, microwave assisted polyol method, non-enzymatic, hydrogen peroxide sensor

\section{$\underline{\text { FULL TEXT }}$}

(C) 2017 The Authors. Published by ESG (www.electrochemsci.org). This article is an open access article distributed under the terms and conditions of the Creative Commons Attribution license (http://creativecommons.org/licenses/by/4.0/). 